\title{
Genomic distribution of three repetitive DNAs in cultivated hexaploid Diospyros spp. (D. kaki and D. virginiana) and their wild relatives
}

\author{
Young A Choi*, Ryutaro Tao, Keizo Yonemori and Akira Sugiura \\ Laboratory of Pomology, Graduate School of Agriculture, Kyoto University, \\ Sakyo-ku, Kyoto 606-8502, Japan
}

(Received 26 February 2003, accepted 28 July 2003)

\begin{abstract}
To understand the genomic organization of Diospyros species with different ploidy levels, we cloned three different repetitive DNAs and compared their genomic distributions in ten Diospyros species, including hexaploid D. kaki and D. virginiana. Genomic Southern hybridization demonstrated that the EcoRVrepetitive DNA was present in tandem in the genomes of D. glandulosa $(2 \mathrm{n}=2 \mathrm{x}=30)$, D. oleifera $(2 \mathrm{n}=2 \mathrm{x}=30)$, D. lotus $(2 \mathrm{n}=2 \mathrm{x}=30), D$. virginiana $(2 \mathrm{n}=6 \mathrm{x}=90)$ and $D$. kaki $(2 \mathrm{n}=6 \mathrm{x}=90)$. All of these species except $D$. virginiana also contained the HincII-repetitive DNA in tandem. Fluorescent in situ hybridization showed that the EcoRV- and HincII-repetitive DNAs were predominantly located at the proximal or centromeric regions of chromosomes. The DraI-repetitive sequence cloned from $D$. ehretioides $(2 \mathrm{n}=2 \mathrm{x}=30)$ was not found in the other Diospyros species tested. This suggests that $D$. ehretioides has a genomic organization different from that of the other Diospyros species. Speciation of hexaploid Diospyros species is also discussed with respect to the genomic distribution of the three repetitive DNAs cloned.
\end{abstract}

Key words: Diospyros, fluorescent in situ hybridization (FISH), persimmon, repetitive DNA, tandem repeat

\section{INTRODUCTION}

The genus Diospyros consists of 400-500 species and consists of species that fall into four ploidy levels, diploid $(2 n=2 x=30)$, tetraploid $(2 n=4 x=60)$, hexaploid $(2 n=6 x=90)$ and nonaploid (2n=9x=135) (Yonemori et al., 2000). Most wild species of Diospyros are diploid, although some are polyploid, while cultivated $D$. kaki and $D$. virginiana are hexaploid. Some seedless cultivars of $D$. kaki are known to be nonaploid (Zhuang et al., 1990; Tamura et al., 1998). A single or several diploid and/or tetraploid wild species may have been involved in the speciation of the cultivated hexaploid and nonaploid species. So far, the phylogenetic relationships of Diospyros species have been discussed based on limited information from analyses of isozymes (Tao and Sugiura, 1987), RFLP of mitochondrial DNA (mtDNA) (Nakamura and Kobayashi, 1994) and PCR-RFLP of chloroplast DNA (cpDNA) (Yonemori et al., 1998).

During the last few decades, a number of studies on plant repetitive DNAs have been performed and detailed

Edited by Minoru Murata

* Corresponding author. E-mail: choi@kais.kyoto-u.ac.jp information about the evolution of and differences among related species has been obtained (Gupta et al., 1990; Schmidt et al., 1991; Schmidt and Heslop-Harrison, 1998). Repetitive DNA elements, such as satellite, minisatellite, and microsatellite DNAs and retrotransposons, constitute the major fraction of nuclear genomes in many higher plants (Bedbrook et al., 1980b; Schmidt and Metzlaff, 1991; Kamm et al., 1994). These repetitive sequences show extensive differences in sequence motifs, abundance and distribution even between closely related species, indicating high species and/or genome specificity (Ingham et al, 1993; Charlesworth et al., 1994). Repetitive sequences are, therefore, useful as new tools for the genome analysis of polyploid species.

In this study, we isolated three repetitive DNAs from Diospyros kaki and two other species, D. oleifera and D. ehretioides, which were assumed to be closely related to D. kaki (Nakamura and Kobayashi, 1994; Yonemori et al., 1998). Genomic DNA blot analysis and fluorescent in situ hybridization (FISH) were performed to investigate the distribution and evolution of these repetitive sequences in the genomes of ten Diospyros species, including hexaploid $D$. kaki and $D$. virginiana. The speciation of hexaploid Diospyros species and genomic organization of 
the ten Diospyros species are discussed based on our results.

\section{MATERIALS AND METHODS}

The ten Diospyros species used in this study are listed in Table 1 with their ploidy levels and regional distributions. The diploid species $D$. glandulosa was suggested as a candidate progenitor species of hexaploid $D$. kaki based on the similarity of distribution area and morphological characters $(\mathrm{Ng}, 1978)$. Other diploids, $D$. oleifera, D. lotus, and D. ehretioides, and hexaploid D. virginiana were reported to be closely related to $D$. kaki as shown by mtDNA or cpDNA analysis (Nakamura and Kobayashi, 1994; Yonemori et al., 1998). These five species were used in this study to investigate genomic similarity among them and to D. kaki. Three species, $D$. rhodocalyx, D. montana, and D. rhombifolia, which were reported to be distantly related to $D$. kaki in spite of having a relatively similar distribution area to $D$. kaki (Yonemori et al., 1998), were used to understand the differences of genomic composition between $D$. kaki and its related species. A species from Southern Africa, $D$. mespiliformis, whose phylogenetic relationship with $D$. kaki remains unknown, was also used in this study. Total DNA of plant materials was extracted from mature leaves by the cetyltrimethylammonium bromide method (Doyle and Dolye, 1987).

Table 1. Ploidy, chromosome number and regional distribution of ten Diospyros species used in this study.

\begin{tabular}{lcl}
\hline Species & $\begin{array}{c}\text { Ploidy and } \\
\text { chromosome } \\
\text { number }\end{array}$ & Regional distribution (climate) \\
\hline D. glandulosa & $2 \mathrm{n}=2 \mathrm{x}=30$ & Southeast Asia (tropical to subtropical) \\
D. oleifera & $2 \mathrm{n}=2 \mathrm{x}=30$ & East Asia (temperate) \\
D. lotus & $2 \mathrm{n}=2 \mathrm{x}=30$ & Central and East Asia (temperate) \\
D. ehretioides & $2 \mathrm{n}=2 \mathrm{x}=30$ & Southeast Asia (tropical to subtropical) \\
D. mespiliformis & $2 \mathrm{n}=2 \mathrm{x}=30$ & Southern Africa (subtropical) \\
D. rhodocalyx & $2 \mathrm{n}=2 \mathrm{x}=30$ & Southeast Asia (tropical) \\
D. montana & $2 \mathrm{n}=2 \mathrm{x}=30$ & Southeast Asia (tropical to subtropical) \\
D. rhombifolia & $2 \mathrm{n}=4 \mathrm{x}=60$ & East Asia (temperate) \\
D. kaki & $2 \mathrm{n}=6 \mathrm{x}=90$ & East Asia (temperate) \\
D. virginiana & $2 \mathrm{n}=6 \mathrm{x}=90$ & Northeast America (temperate)
\end{tabular}

Cloning and sequencing of repetitive DNAs Total DNA of $D$. kaki was digested with $E c o$ RV, fractionated by electrophoresis on a $0.8 \%$ agarose gel, and stained with ethidium bromide (EtBr). The restriction profile showed a ladder of bands corresponding to multimeric DNA fragments of a basic repeat unit of approximately $200 \mathrm{bp}$ in length. This basic repeat of $200 \mathrm{bp}$ was eluted from the gel and cloned into the EcoRV site of pBluescriptII (-). Total DNA of D. oleifera digested with HincII and total
DNA of D. erhetioides digested with DraI were fractionated electrophoretically. A basic repeat of $200 \mathrm{bp}$ of $D$. oleifera and a band of $160 \mathrm{bp}$ of $D$. ehretioides were cloned into the HincII and EcoRV sites of pBluescriptII (-), respectively. Several clones each for the repetitive DNAs were sequenced with an automatic DNA sequencer (ABI PRISM, Applied Biosystems, CA, U.S.A.). The repetitive sequences obtained were labeled with digoxigenin (DIG)-11-dUTP by the direct PCR labeling system according to the supplier's instructions (Roche, Mannheim, Germany) and used as probes for genomic Southern blot analysis and FISH. The nucleotide sequences have been registered in the DDBJ/EMBL/GeneBank under the accession numbers AB107228 to AB107230.

Southern blot hybridization Total DNAs $(1 \mu \mathrm{g})$ of Diospyros species digested with three kinds of restriction endonucleases previously used in cloning of repetitive DNAs were electrophoresed on a $0.8 \%$ agarose gel and transferred to a nylon membrane (Hybond-N, Amarsham Pharmacia Biotech, NJ, U.S.A.). The membrane was probed with denatured DIG-labeled repetitive DNA at $60^{\circ} \mathrm{C}$ overnight. After washes $\left[2 \times 15 \mathrm{~min}\right.$ at $60^{\circ} \mathrm{C}$ with $0.1 \times \mathrm{SSC}(20 \times \mathrm{SSC}$ consists of $3 \mathrm{M} \mathrm{NaCl}$ and $0.3 \mathrm{M}$ sodium citrate) and $0.1 \%(\mathrm{w} / \mathrm{v})$ sodium dodecylsulfate], colorimetric detection of the hybridization was carried out using nitro blue tetrazolium and 5-bromo-4-chloro-3indolyl phosphate $p$-toluidine salt according to the manufacturer's protocol (Roche, Mannheim, Germany).

Fluorescent in situ hybridization (FISH) Chromosome preparation, pretreatment with RNase and FISH were conducted as described before (Choi et al., 2003) with slight modifications. Briefly, root tips of $D$. kaki and D. lotus were excised and pretreated with $2 \mathrm{mM} 8$ hydroquinolin solution for $5 \mathrm{hrs}$ at $4^{\circ} \mathrm{C}$ and fixed in a methanol-acetic acid solution $(3: 1, \mathrm{v} / \mathrm{v})$. Chromosome spreads were prepared by an enzymatic maceration method (Fukui, 1996). The hybridization mixture contained $200 \mathrm{ng}$ of the DIG-labeled probe per slide dissolved in $15 \mu \mathrm{l}$ of $50 \%$ formamide in $2 \times$ SSC. The probe mixture was denatured, applied to the slide and covered with a cover slip that was sealed with rubber bond. The chromosomes and probe mixture on the slides were denatured at $80^{\circ} \mathrm{C}$ for $10 \mathrm{~min}$ and the hybridization was performed at $37^{\circ} \mathrm{C}$ for 2 days. After washing with $2 \times \mathrm{SSC}$, $50 \%$ formamide in $2 \times \mathrm{SSC}$ and $4 \times \mathrm{SSC}$, each at $42^{\circ} \mathrm{C}$ for $10 \mathrm{~min}$, the chromosome spreads were blocked with $5 \%$ $(\mathrm{w} / \mathrm{v})$ bovine serum albumin (BSA) in BT buffer $(0.1 \%$ sodium hydrogen carbonate, $\mathrm{pH} 8.3$ ) at $37^{\circ} \mathrm{C}$ for 5 min. Ten percent (v/v) anti-DIG-fluorescein isothiocyanate (FITC) (Roche, Mannheim, Germany) in 1\% (w/v) BSA in BT buffer was dropped onto the chromosomes and incubated at $37^{\circ} \mathrm{C}$ for $60 \mathrm{~min}$. Subsequent steps were the same as described by Choi et al. (2003). The chromo- 
somes were observed with a fluorescence microscope (Axiophot, Zeiss, Oberkochen, Germany) with a high-sensitivity cooled CCD camera (PXL 1400, Photometrics, Ariz., U.S.A.). The FISH signals were analyzed with imaging software (IPLab Spectrum 3.1, Signal Analytics, CA, U.S.A.).

\section{RESULTS}

Repetitive DNAs in EcoRV-digests A strong band of about $200 \mathrm{bp}$ (designated the EcoRV-repeat) was observed in the EtBr-stained gel of the EcoRV-digests of D. kaki, $D$. glandulosa, D. oleifera, D. lotus and D. virginiana genomic DNA (Fig. 1A). The band of D. kaki was cloned, and three of 12 clones obtained were sequenced. The 194-bp repeat unit was relatively AT-rich (67\% AT) and contained a pair of inverted subrepeats within the sequence (Fig. 2A; arrows). No significant homology with this sequence was found in the DNA databases. Stop codons were present in all reading frames of the monomer sequences, suggesting that the members of the EcoRV-repetitive DNA family do not encode any protein (data not shown). Southern hybridization of EcoRVdigests of the ten Diospyros species with the EcoRVrepeat as a probe revealed typical ladder band patterns of tandem repeats in the five species, although minor differences were found among them in the signal intensity and ladders of bands (Fig. 1D). Southern hybridization was also performed by hybridizing the same probe to the BamHI-digests of the five species that had signals in the EcoRV-digests. Only D. virginiana showed a ladder pattern, while the other species had smear hybridization patterns (data not shown). FISH detected signals of the $E c o R V$-repeat probe on the metaphase chromosomes of $D$. lotus and D. kaki (Fig. 3). Signals appeared predominantly at the proximal or centromeric regions of the chromosomes, where strong DAPI bands were observed in the two species (Fig. 3A-C and D-F). Almost all chromosomes of $D$. lotus and approximately 70 of the 90 chromosomes of $D$. kaki showed the signals of the EcoRV-repeat

\section{EcoRV-digests}

(A)

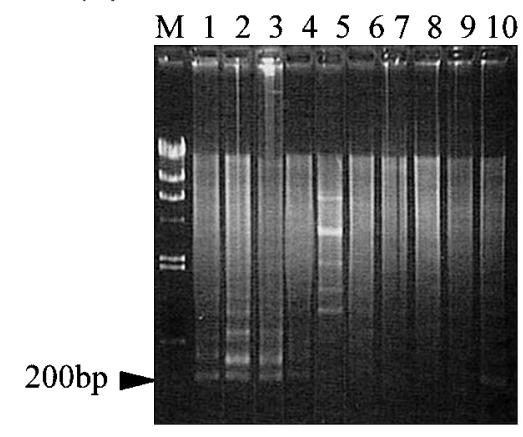

(D)

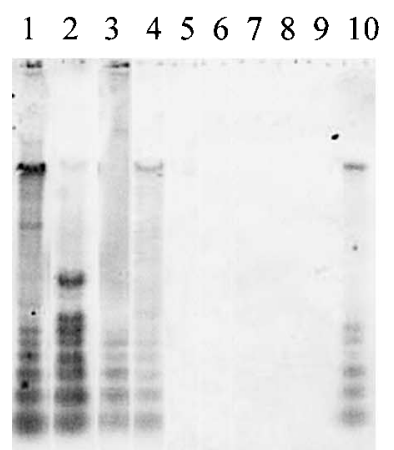

Hinc II -digests

(B)

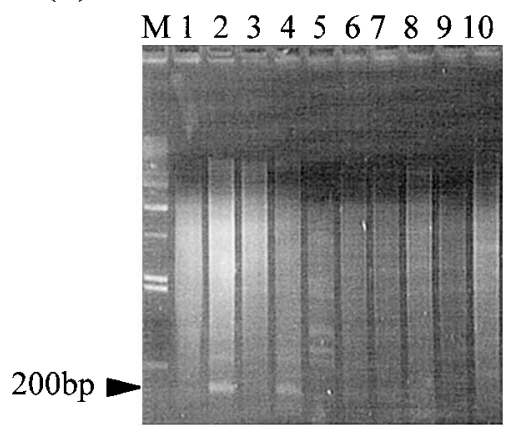

(E)

$\begin{array}{llllllllll}1 & 2 & 3 & 4 & 5 & 6 & 7 & 8 & 9 & 10\end{array}$

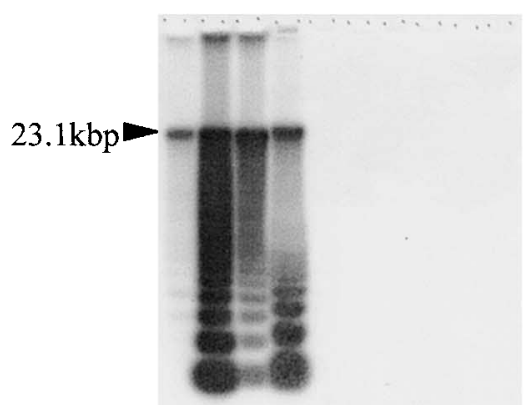

DraI -digests

(C)

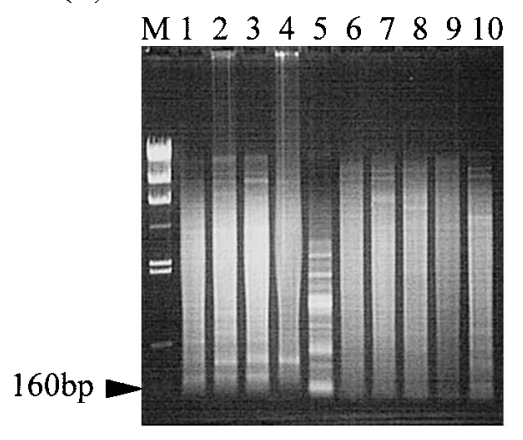

(F)

Fig. 1. Analysis of the EcoRV, HincII and DraI repetitive DNAs in ten Diospyros species. Upper figures (A-C) show ethidium bromide-stained gels of electrophoretically separated genomic DNA digested with EcoRV, HincII and DraI. Lower figures (D-F) show the Southern blots of the respective agarose gels probed with the EcoRV, HincII and DraI repeat probes. (A), (D) EcoRV repetitive DNA; (B), (E) HincII repetitive DNA; (C), (F) DraI repetitive DNA: lane 1, D. kaki; lane 2, D. oleifera; lane 3, D. glandulosa; lane 4, D. lotus; lane 5, D. ehretioides; lane 6, D. mespiliformis; lane 7, D. rhodocalyx; lane 8, D. montana; lane 9, D. rhombifolia; lane 10, D. virginiana; lane $\mathrm{M}, \lambda$ HindIII digest. 
A
1 gatatcttga aatatactta tttgatgatg acgatttcaa atctaggaca
51 aagatgacag tttgatgcac tttatacaca caagaagtt taattctga
101 tttgggaag ttttcaaag ttgagtttta ggcatgggtc catagtagaa
151 catttaaac aagaaggaga ccatactgat tcaatcaacg attcgatatc

(AT content $67 \%$ )

$\mathbf{B}$

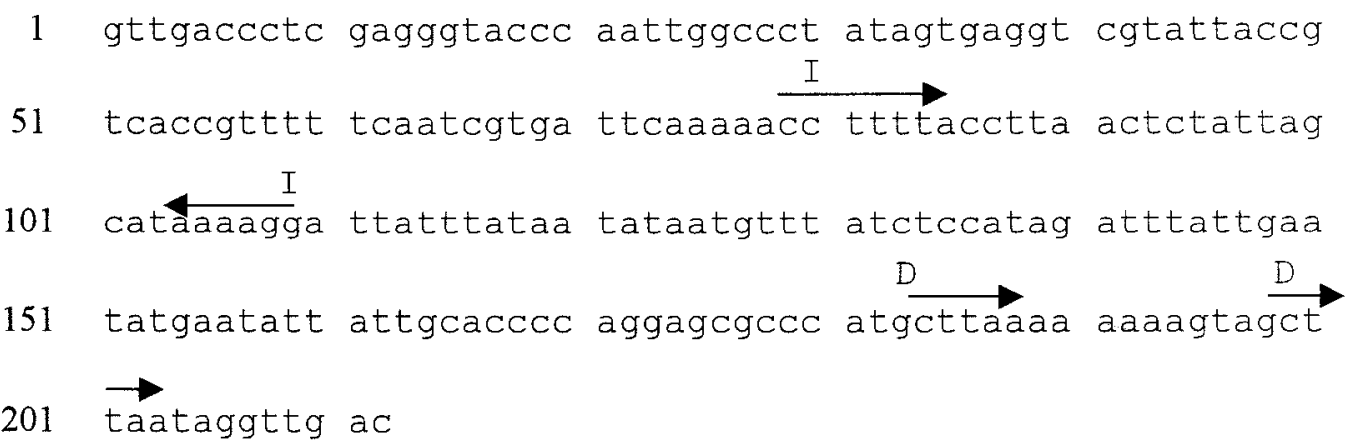

(AT content $65 \%$ )

C

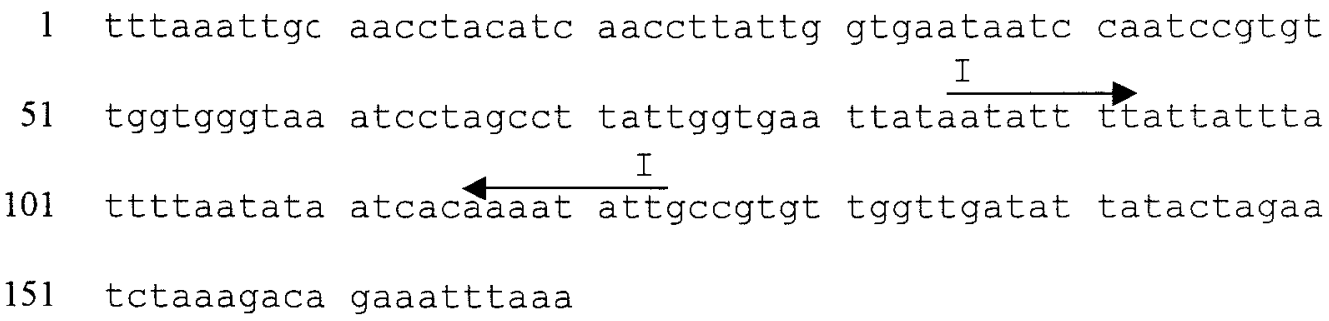

\section{(AT content 71\%)}

Fig. 2. Nucleotide sequences of the cloned repeat fragment of each repetitive DNA. (A) the EcoRV-repeat fragment from D. kaki, (B) the HincII-repeat fragment from D. oleifera, and (C) the DraI-repeat fragment from D. ehretioides. Arrows indicate direct (D) or inverted (I) subrepeats in the nucleotide sequence of each repetitive DNA. Nucleotide sequence data reported here are available in the DDBJ database under the accession numbers AB107228 to AB107230.

probe.

Repetitive DNAs in HincII-digests After HincII digestion and electrophoresis of genomic DNA, EtBr staining showed a prominent band in D. oleifera and D. lotus (Fig. 1B). This 200-bp band was cloned from $D$. oleifera, and two of nine clones obtained were sequenced. The 206-bp repeat unit of the HincII-fragment showed an AT content of $65 \%$ (Fig. 2B). The presence of subrepeats was detected as in the EcoRV-repeat, but no significant homology was found between the HincII-repeat and the EcoRVrepeat. Southern blot hybridization with the HincIIrepeat as a probe also showed ladder patterns in three species, D. oleifera, D. glandulosa and D. lotus (Fig. 1E). This indicates that the HincII-repeats are also arranged in tandem. In the digest of $D$. $k a k i$, a weak 

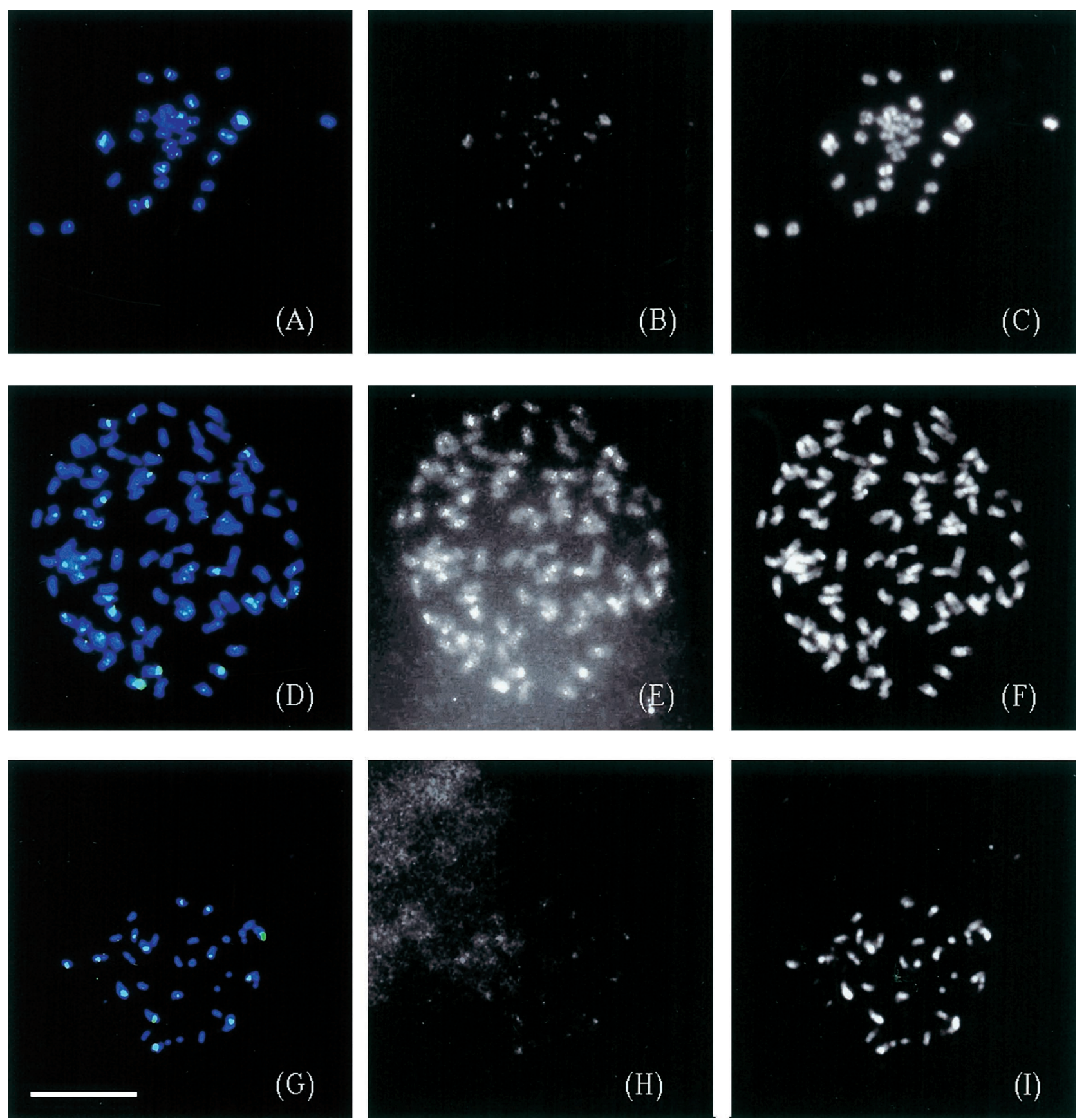

Fig. 3. Localization of the EcoRV (A-F) and HincII (G-I) repetitive DNAs on chromosomes of D. lotus (2n=2x=30) and D. kaki $(2 \mathrm{n}=6 \mathrm{x}=90)$. (A) Colored and merged images of FITC signals (green) of the EcoRV repeat probe and the DAPI-stained chromosomes of D. lotus (blue). (B) FITC signals of the EcoRV repeat probe in the same metaphase spread after FISH. (C) DAPI-stained metaphase chromosomes in the same spread (D) Colored and merged images of FITC signals of the EcoRV repeat probe and the DAPIstained chromosomes of D. kaki. (E) FITC signals of the EcoRV repeat probe in the same metaphase spread after FISH. (F) DAPIstained metaphase chromosomes in the same spread. (G) Colored and merged images of FITC signals of the HincII repeat probe and the DAPI-stained chromosomes of D. lotus. (H) FITC signals of the HincII repeat probe in the same metaphase spread after FISH. (I) DAPI-stained metaphase chromosomes in the same spread. Bar represents $10 \mu \mathrm{m}$.

ladder pattern was observed, but monomeric and dimeric bands were missing and a 23.1-kb band was clear (Fig. $1 \mathrm{E}$; arrowhead). The lack of hybridization signals in the D. virginiana digest suggested that the HincII-repeats do not exist in this genome. The FISH signals were detected at the proximal or centromeric regions of $D$. lotus chromosomes, which corresponded to the DAPI bands (Fig. 3G-I). No FISH signals appeared on the chromosomes of D. kaki (data not shown). 
Repetitive DNAs in DraI-digests EtBr-gel staining revealed the presence of DraI-bands in the digests of genomic DNA of six species, D. kaki, D. glandulosa, D. oleifera, D. lotus, D. virginiana and D. ehretioides (Fig. 1C). Among those bands, a 160-bp band from D. ehretioides was cloned, and two of 11 clones obtained were sequenced. The 164-bp repeat unit of the DraI-fragment had an AT content of $71 \%$ (Fig. 2C). This DraI-repeat also had a pair of subrepeats, but no significant homology to these repeat sequences was found in the DNA databases. Southern hybridization with the DraI-repeat as a probe revealed that this sequence exists only in the D. ehretioides genome (Fig. 1F). No clear ladder pattern was observed, although several bands appeared in the range of 160-300 bp. This suggests that the organization of the DraI-repetitive DNA is different from those of the other repetitive DNAs cloned here. No FISH signals were detected on the chromosomes of $D$. ehretioides (data not shown).

\section{DISCUSSION}

The typical ladder patterns observed in Southern blot hybridization with the EcoRV- and HincII- repeat as probes (Fig. 1D, E) suggested that these sequences are arrayed in tandem in the genomes of Diospyros species, as previously shown in other plant species (Iwabuchi et al., 1991; Kamm et al., 1994). The FISH signals from the EcoRV- and HincII- repeats coincided with the proximal and/or centromeric DAPI bands, which coincide with Giemsa bands in D. kaki and D. lotus (unpublished data). Giemsa bands reveal centromeric heterochromatin (Schwarzacher et al., 1980) and tandemly arrayed repetitive DNA is frequently localized in heterochromatin (Flavell, 1980). These sequences thus appeared to be components of proximal and/or centromeric heterochromatin in D. kaki and D. lotus, similar to other centromeric repetitive sequences (Murata et al., 1994; Kishii et al., 2001). Although the DraI-repetitive DNA in D. ehretioides showed a different hybridization pattern, three tandem repeats ranging from 160 to $200 \mathrm{bp}$ similar to the 180-bp repeat in Arabidopsis thaliana (Murata et al., 1994) were detected.

No DNA sequences similar to the EcoRV- and HincIIrepeats were detected by Southern hybridization in $D$. rhodocalyx, D. mespilifromis, D. montana and D. rhombifolia which are morphologically different from $D$. kaki (Utsunomiya et al., 1998; Yonemori et al., 1998). This suggests that both of these repetitive sequences are specific to $D$. kaki and its closely related species. The EcoRV-repeat was detected in five species: $D$. kaki, $D$. glandulosa, $D$. oleifera, $D$. lotus and $D$. virginiana. The HincII-repeat was also found in those species, except for in $D$. virginiana. This is noteworthy, because $D$. virginiana was classified as a monophyletic group with $D$. kaki and $D$. lotus by cpDNA analysis (Yonemori et al., 1998).

The different genomic distributions of the EcoRV- and the HincII- repetitive DNAs suggests that the EcoRVrepetitive DNA may have evolved earlier and that the amplification of the HincII-repetitive DNA occurred after the divergence of $D$. virginiana, as suggested previously for two satellites isolated from Beta vulgaris (Schmidt et al., 1991). In Southern blots of BamHI-digests with the EcoRV-repeat probe, a ladder pattern was observed only for $D$. virginiana (data not shown). These results suggest that the genomic evolution of $D$. virginiana after speciation was different from that of $D$. kaki and its related species. Nakatsuka et al. (2002) also suggested that $D$. virginiana was unlikely to be related to $D$. kaki in that a subgroup of Ty1-copia group retrotransposons was markedly increased in only $D$. virginiana of the species tested. The lack of significant sequence homology between the EcoRV- and HincII- tandem repeats also suggests that these two sequences evolved from different ancestral sequences, as shown previously in other plant species (Schmidt and Metzlaff, 1991). Tetraploid Hordeum murinum was suggested to be allopolyploid in that a cloned repetitive DNA was found in $H$. murinum $(4 \mathrm{x})$ but not in its identified diploid ancestor (Taketa et al., 2000). Taken together, these facts suggest that different ancestral species might have been involved in the speciation of $D$. virginiana and $D$. kaki.

The detection of the FISH signal of the EcoRV-repeat probe on the chromosomes of diploid D. lotus and hexaploid $D$. kaki suggest that a diploid with the EcoRV-repetitive DNA, such as D. glandulosa, D. oleifera and D. lotus, was involved in the speciation of D. kaki. Furthermore, the fact that almost all chromosomes of D. lotus and approximately 70 of the 90 chromosomes of $D$. kaki carry the EcoRV-repeat might imply that several species with very similar genomic composition were involved in the speciation of $D$. kaki. The observation of the segregation pattern of a molecular marker linked to natural astringency loss (Kanzaki et al., 2001) and four sets of chromosomes carrying 45S rDNA (Choi et al., 2003) suggested that $D$. kaki could be an autohexaploid or autoallohexaploid.

The presence of the EcoRV- and HincII- repetitive DNAs in $D$. glandulosa and $D$. oleifera reveals a certain degree of similarity of the genomic organization of these two diploids with that of D. kaki and D. lotus. The morphological features suggest that $D$. glandulosa could be one of the progenitor species of hexaploid $D$. kaki $(\mathrm{Ng}$, 1978). The genomic background of $D$. ehretioides, a putative progenitor species of $D$. kaki, may be different from that of the other Diospyros species tested. The numerous satellite bands of $D$. ehretioides (Fig. 1A-C, lane 5) may contribute to the increased chromosomal length (Choi et al., 2003) and genome size (twice as much as that of hexaploid D. kaki; unpublished data of this 
species). Amplification of satellite DNAs has been postulated to be one of the causes of the increase of genome size and chromosomal length in plant species (Uozu et al., 1997; Torrell and Valles, 2001; Valarik et al., 2002). In chloroplast DNA analysis, D. glandulosa and D. oleifera were classified in a monophyletic group with $D$. rhombifolia and D. montana while D. ehretioides was classified in the same clade as $D$. kaki, D. lotus and D. virginiana (Yonemori et al., 1998). Chloroplast DNA is inherited uniparentally in a strictly maternal fashion (Smith, 1989) and may not reflect the precise relationships of closely related species. The result of a recent study of the sequence of the ITS and $m a t \mathrm{~K}$ regions were in agreement with our results here showing the closest relationship between $D$. kaki and three diploids, $D$. glandulosa, $D$. oleifera and D. lotus (Ino et al., 2002).

Rearrangement of the repetitive DNAs seems to have taken place in the genome of Diospyros species after speciation. D. kaki had a strong signal with the HincIIrepeat probe in the range of $23.1 \mathrm{~kb}$ (Fig. $1 \mathrm{E}$ ). This may be the relic DNA (Bedbrook et al., 1980a) that was suggested to have diverged without sequence amplification and to have been rearranged in a large cluster by losing the restriction site and/or by C-methylation during the evolution of cereal plant species (Iwabuchi et al., 1991; Martinez-Zapater et al., 1986). The several DraI-bands corresponding to smaller fragments in the $D$. ehretioides digest (Fig. 1F) suggest that the DraI-sequence family is dispersed in the $D$. ehretioides genome, like satellite DNA of Beta vulgaris (Schmidt and Metzlaff, 1991). Different signal intensity of the repeat probe in FISH analysis, such as that seen in Fig. 3, has also been reported to be the result of rearrangement and/or amplification of subrepeats (Kamm et al., 1995; Schmidt et al., 1991).

The mechanism of the deletion and diversification of these repetitive sequence families remains to be studied, along with the genome constitution of Diospyros species, and will be critical for elucidating the mechanism of speciation of $D$. kaki and its related species. In addition to providing information about the speciation of the hexaploid $D$. kaki and $D$. virginiana, the repetitive sequence analysis should be useful for the studying the genomic evolution of Diospyros species at the molecular level.

\section{REFERENCES}

Bedbrook, J. R., Jones, J., O’Dell, M., Thompson, R. D., and Flavell, R. B. (1980a) A molecular description of telomeric heterochromatin in Secale species. Cell 19, 545-560.

Bedbrook, J. R., O'Dell, M., and Flavell, R. B. (1980b) Amplification of rearranged repeated DNA sequences in cereal plants. Nature 288, 133-137.

Charlesworth, B., Sniegowski, P., and Stephan, W. (1994) The evolutionary dynamics of repetitive DNA in eukaryotes. Nature 371, 215-220.
Choi, Y. A., Tao, R., Yonemori, K., and Sugiura, A. (2003) Physical mapping of $45 \mathrm{~S}$ rDNA by fluorescent in situ hybridization in persimmon (Diospyros kaki) and its wild relatives. J. Hort. Sci. Biotech. 78, 265-271.

Doyle, J. J., and Doyle, J. L. (1987) A rapid DNA isolation procedure for small quantities of fresh leaf tissue. Phytochem. Bul. 19, 11-15.

Flavell, R. (1980) The molecular characterization and organization of plant chromosomal DNA sequences. Ann. Rev. Plant. Physiol. 31, 569-596.

Fukui, K. (1996) Plant chromosomes at mitosis. In: Plant chromosomes: Laboratory methods (eds.: Fukui, K., and Nakayama, S.), pp.1-17. CRC Press, Boca Raton, FL.

Gupta, V., Jagannathan, V., and Lakshmikumaran, M. S. (1990) A novel AT-rich tandem repeat of Brassica nigra. Plant Sci. 68, 223-229.

Ingham, L. D., Hanna, W. W., Baier, J. W., and Hannah, L. C. (1993) Origin of the main class of repetitive DNA within selected Pennisetum species. Mol. Gen. Genet. 238, 350 356.

Ino, H., Yonemori, K., and Sugiura, A. (2002) Phylogenetic analysis of the genus Diospyros based on the ITS and matK sequences. J. Jpn. Soc. Hort. (Supplement). 71(1), p 69.

Iwabuchi, M., Itoh, K., and Shimamoto, K. (1991) Molecular and cytogenetic characterization of repetitive DNA sequences in Brassica. Theor. Appl. Genet. 81, 349-355.

Kamm, A., Schmidt, T., and Heslop-Harrison, J. S. (1994) Molecular and physical organization of highly repetitive, undermethylated DNA from Pennisetum glancum. Mol. Gen. Genet. 244, 420-425.

Kamm, A., Galasso, I., Schmidt, T., Heslop-Harrison, J. S. (1995) Analysis of a repetitive DNA family from Arabidopsis arenosa and relationships between Arabidopsis species. Plant. Mol. Biol. 27, 853-862.

Kanzaki, S., Yonemori, K., Sugiura, A., Sato, A., and Yamada, M. (2001) Identification of molecular markers linked to the trait of natural astringency loss of Japanese persimmon (Diospyros kaki) fruit. J. Amer. Soc. Hort. Sci. 126, 51-55.

Kishii, M., Nagaki, K., and Tsujimoto, H. (2001) A tandem repetitive sequence located in the centromeric region of common wheat (Triticum aestivum) chromosomes. Chromosoma $\mathbf{9}$, 417-428.

Martinez-Zapater, J. M., Estelle, M. A., and Somerville, C. R. (1986) A highly repeated DNA sequence in Arabidopsis thaliana. Mol. Gen. Genet. 204, 417-423.

Murata, M., Ogura, Y., and Motoyoshi, F. (1994) Centromeric repetitive sequences in Arabidopsis thaliana. Jpn. J. Genet. 69, 361-370.

Nakamura, Y., and Kobayashi, S. (1994) DNA restriction fragment length variability in Diospyros kaki and related Diospyros species. HortSci. 29, 809-811.

Nakatsuka, A., Iwami, N., Matusmoto, S., Itamura, H., and Yamagashi, M. (2002) Ty1-copia group retrotransposon in persimmon (Diospyros kaki Thunb.) Genes Genet. Syst. 77, 131-136.

Ng, F. S. P. (1978) Diospyros roxburghii and the origin of Diospyros kaki. Malaysian Forester 41, 43-50.

Schmidt, T., Jung, C., and Metzlaff, M. (1991) Distribution and evolution of two satellite DNAs in the genus Beta. Theor. Appl. Genet. 82, 793-797.

Schmidt, T., and Metzlaff, M. (1991) Clonging and characterization of a Beta vulgaris satellite DNA family. Gene 101, $247-250$.

Schmidt, T., and Heslop-Harrison, J. S. (1998) Genomes, genes and junk: the large-scale organization of plant chromo- 
somes. Trends in Plant Sci. 3, 195-199.

Schwarzacher, T., Ambros, P., and Schweizer, D. (1980) Application of Giemsa banding to orchid karyotype analysis. Plant Syst. Evol. 134, 293-297.

Smith, S. E. (1989) Biparental inheritance of organelles and its implications in crop improvement. Plant Breed. Rev. 6, 361-393.

Taketa, S., Ando, H., Takeda, K., Harrison, G. E., and HeslopHarrison, J. S. (2000) The distribution, organization and evolution of two abundant and wildspread repetitive DNA sequences in the genus Hordeum. Theor. Appl. Genet. 100, 169-170.

Tamura, M., Tao, R., Yonemori, K., Utsunomiya, N., and Sugiura, A. (1998) Ploidy level and genome size of several Dioispyros species. J. Jpn. Soc. Hort. Sci. 67, 306-312.

Tao, R., and Sugiura, A. (1987) Cultivar identification of Japanese persimmon by leaf isozymes. HortSci. 22, 932-935.

Torell, M., and Valles, J. (2001) Genome size in 21 Arteumisia L. species (Asteraceae, Anthemideae): Systematic, evolutionary, and ecological implications. Genome 44, 231-238.

Uozu, S., Ikehashi, H., Ohmido, N., Ohtsubo, H., Ohtsubo, E., and Fukui, K. (1997) Repetitive sequences: cause for varia- tion in genome size and chromosome morphology in the genus Oryza. Plant. Mol. Biol. 35, 791-799.

Utsunomiya, N., Subhadrabandhu, S., Yonemori, K., Oshida, M., Kanzaki, S., Nakatsubo, F., and Sugiura, A. (1998) Diospyros species in Thailand: their distribution, fruit morphology and uses. Economic Botany 52, 343-351.

Valarik, M., Simkova, H., Hribova, E., Safar, J., Dolezelova, M., and Dolezel, J. (2002) Isolation, characterization and chromosome localization of repetitive DNA sequences in bananas (Musa spp.). Chromosome Res. 10, 89-100.

Yonemori, K., Kanzaki, S., Parafitt, D. E., Utsnomiya, N., Subhadrabandhu, S., and Sugiura, A. (1998) Phylogenetic relationship of Diospyros kaki (persimmon) to Diospyros spp. (Ebenaceae) of Thailand and four temperate zone Diospyros spp. from an analysis of RFLP variation in amplified cpDNA. Genome 41, 173-182.

Yonemori, K., Sugiura, A., and Yamada, M. (2000) Persimmon genetics and breeding. Plant Breed. Rev. 19, 191-225.

Zhuang, D. H., Kitajima, A., Ishida, M., and Sobajima, Y. (1990) Chromosome numbers of Diopyros kaki cultivars. J. Jpn. Soc. Hort. Sci. 59, 289-297. 